\title{
Inclusion of Diverse Learners in the Educational System ${ }^{1}$
}

\author{
Eric D. Rubenstein and Andrew C. Thoron²
}

\section{Introduction}

Every student in the United States has the right to an education. However, not every student is ready, prepared, or willing to learn. Ensuring that students are fully engaged in the learning environment has become increasingly difficult for teachers (Schunk, 2012), especially when working with students from diverse backgrounds. Diversity is defined as the differences among individuals. More specifically in an educational setting, diversity refers to the differences among students based upon: socioeconomic status, ethnicity/race, learning style, cognitive ability, gender, and ability to process and store knowledge (National Education Association, n.d.). These forms of diversity have caused for an "achievement gap" to form between students. This paper is focused on highlighting several educational strategies that have proven effective in engaging students in the learning environment and assisting in closing achievement gaps.

\section{What is Diversity?}

There are three accepted categories of diversity within school settings: race/ethnicity, learning modality, and socioeconomic status (Tileston, 2004). The race/ethnicity of a student has been shown to influence their performance within the school system. This concern can be seen in many schools within the United States public school system, but it is especially prevalent in urban and suburban schools that have higher rates of racial/ethnic diversity.
Learning modality refers to how a student best learns within the learning environment. The three learning modalities recognized within education are visual, auditory, and kinesthetic (Sousa, 1995). Visual learners acquire information most effectively by seeing or reading the material, auditory learners by hearing the material read aloud or presented to them, and kinesthetic learners learn through hands-on interactions with the material, concept, or skill.

Socioeconomic status, which is based upon annual family income, is a strong predictor of performance within the school system (Coleman, 1966). Students from low socioeconomic status families tend to "live in the now," rather than planning for the future (Payne, 2001). Therefore, a student of low socioeconomic status typically will focus on utilizing available resources to overcome immediate issues and constraints, rather than saving resources to prepare for concerns or issues of the future. In turn, students of low socioeconomic status may not see the value or need for an education.

\section{Learning Strategies}

The use of a variety of learning strategies has been found to be effective when working with students from diverse backgrounds. Learning strategies or instructional strategies vary based upon the needs of the students. Five learning strategies have been identified as beneficial for promoting student learning: 1) setting high expectations, 2) self-system of learning, 3) conveying the importance of the lesson, 4)

1. This document is AEC487 (formerly WC150), one of a series of the Agricultural Education and Communication Department, UF/IFAS Extension. Original publication date July 2013. Visit the EDIS website at http://edis.ifas.ufl.edu.

2. Eric D. Rubenstein, graduate assistant, and Andrew C. Thoron, assistant professor, Agricultural Education and Communication Department, UF/IFAS Extension, Gainesville, FL 32611. 
promoting self-efficacy, and 5) understanding the student's emotions (Tileston, 2004).

\section{Setting High Expectations}

Setting high expectations will assist the student in achieving greater learning gains. Not only will setting high expectations improve student learning, but high expectations will encourage the teacher to develop a more rigorous curriculum (Tileston, 2004). Further, students will model their teacher's successful demonstrated behaviors (Schunk, 2012). If teachers set high expectations that are obtainable and provide students with the means to achieve the set expectations, then students will model the needed behavior to achieve the established goal or expectation.

\section{EXAMPLE}

Mrs. Baker is teaching an Agriscience Foundations course with 21 students. In past years, she has received work that did not meet her expectations. This year, Mrs. Baker established and presented her expectations for each student on the first day of the course. Additionally, Mrs. Baker developed specific expectations she had for each assignment she included in her course. During the first semester, student scores and work showed improved quality and retention of information over previous classes.

\section{Self-System of Learning}

The self-system of learning refers to the way that students perceive their own abilities, attributes, relationships/ interactions with others, as well as their overall purpose in life. Teachers must continue to understand their students' strengths and weaknesses to enhance their learning and engagement within the classroom (Schunk, 2012). By understanding each student's attributes and abilities, a teacher can involve the student in the classroom setting and increase their motivation to participate and engage in the learning environment (Tileston, 2004).

\section{EXAMPLE}

During class, Mr. Brown notices that Mario is not engaged while they are working at the land lab during his Agri Technology course. Mr. Brown remembers that Mario enjoys fishing. With this in mind, he assigns Mario to conduct a bi-weekly measurement of the fish in the aquaculture pond.

\section{Importance of Lesson}

When working with students from diverse backgrounds, teachers should try to relate the importance of the concept or knowledge to students' life experiences (Marzano, 2001; Tileston, 2004). During the anticipatory set of each lesson, a teacher should state the importance of the daily learning activities and describe the relevance of the lesson to the students' lives. The teacher should also establish a connection between the students' prior knowledge and the concepts that will be taught during the lesson. Students must have a firm understanding of the importance of the material to become fully engaged and retain the information provided (Schunk, 2012).

\section{EXAMPLE}

When instructing students on non-renewable resources, Mrs. Martinez emphasizes the ways in which the use of non-renewable resources will impact their everyday lives, such as how they will make financial decisions when they own their own homes, or how their decisions will affect the Earth's natural resources.

\section{Self-Efficacy}

Self-efficacy is defined as the student's perception of their ability to produce a given behavior at a given time (Bandura, 1986). An individual's self-efficacy towards a behavior or concept can change over time due to the individual's interactions with the learning environment and newly provided information about the behavior or concept (see Figure 1). By understanding and providing for a student's self-efficacy towards a concept or behavior, the learning environment can become more positive for the student. During lessons, the teacher must continue to establish obtainable goals for students. If students continue to experience failure in life and the classroom, they develop a condition commonly called learned helplessness. Learned helplessness normally occurs when a student has developed negative perceptions about learning due to the home environment. Through obtainable goal-setting and positive interactions with teachers and the learning environment, students with learned helplessness can become successful and engaged in classroom activities.

\section{EXAMPLE}

Mr. Jackson has noticed that the students in his class have begun to doubt their abilities to complete a project he assigned. To increase the students' motivation and their perception of their abilities, Mr. Jackson discusses with his students the goals and expectations of the project. During their discussion, Mr. Jackson provided a clear description and suggestions on how they can achieve each goal and expectation for the project. 


\section{Behavior}
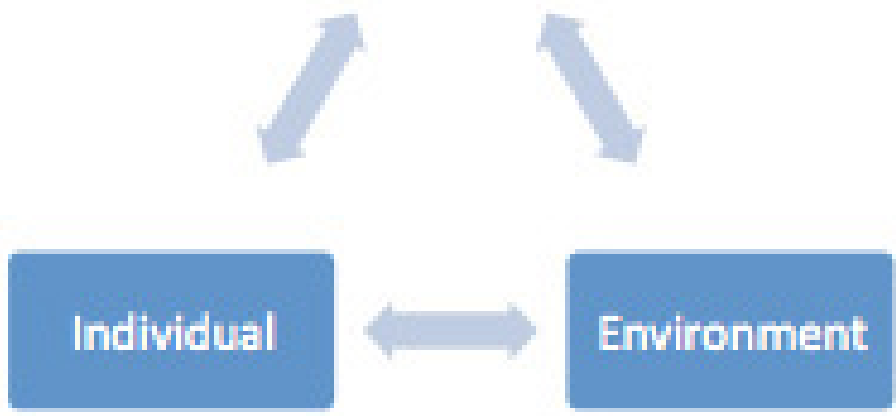

Figure 1. Bandura's Triadic Reciprocality Model (Bandura, 1986).

\section{Student Emotions}

Emotions play a large role in a student's ability to learn in any situation (Schunk, 2012). Students must have their physiological and safety needs met before the body can fully function and begin the learning process (Schunk, 2012). A teacher must have an understanding of major events that are occurring within students' lives, and be willing to accommodate learning activities based upon given situations.

\section{EXAMPLE}

Mr. Rodriguez notices that Janine, one of his students in an Agriscience Foundation course, is frustrated or upset. After talking with her, Mr. Rodriguez realizes that Janine's frustration is affecting her ability to focus on a learning activity. Therefore, Mr. Rodriguez writes Janine a pass to meet with the guidance counselor to further discuss her emotional concerns.

\section{Conclusion}

When teaching students from diverse backgrounds, teachers must take into consideration various factors that influence each student's engagement and learning potential within the classroom setting. Teachers can encourage a student to become engaged in the learning environment by setting obtainable goals, having high expectations for student learning, and conveying the importance of the concept or skill. Further, a teacher can influence a student's engagement and learning in the classroom by knowing that student's strengths, weaknesses, abilities, emotions, and perceptions (see Table 1 for further considerations on how to improve instruction for diverse learners). If teachers consider each of these factors when preparing lessons for their students, the achievement gap may well begin to close.

\section{References}

Bandura, A. (1986). Social foundations of thought and action: A social cognitive theory. Englewood Cliffs, NJ: Prentice Hall.

Coleman, J. S. (1966). Equality of educational opportunity (Report No. OE-3800). Washington, DC: National Center for Educational Statistics.

Marzano, R. J. (2001). Designing a new taxonomy of educational objectives. Thousand Oaks, CA: Corwin Press.

National Education Association. (n.d.) Diversity toolkit introduction. Retrieved from http://www.nea.org/tools/ diversity-toolkit-introduction.html

Payne, R. K. (2005). A framework for understanding poverty, $4^{\text {th }}$ edition. Highlands, TX: aha Process, Inc.

Schunk, D. H. (2012). Learning theories: An educational perspective ( $\left.6^{\text {th }} \mathrm{Ed}\right)$. Boston, MA: Pearson Education.

Sousa, D. (1995). How the brain learns. Reston, VA: National Association of Secondary School Principals.

Tileson, D. W. (2004). What every teacher should know about diverse learners. Thousand Oaks, CA: Corwin Press.

Eric. D. Rubenstein is a graduate student in the Agricultural Education \& Communication Department at the University of Florida.

Andrew C. Thoron is an Assistant Professor in the Agricultural Education \& Communication Department at the University of Florida. Contact information: athoron@ufl. edu 
Table 1. Considerations for Implementing Teaching Strategies

\begin{tabular}{|c|c|}
\hline Teaching Strategy & Considerations for Implementation \\
\hline Setting High Expectations & $\begin{array}{l}\text { - Know your students' strengths and weaknesses. } \\
\text { - Set goals that are achievable by all students in the classroom. } \\
\text { - Ensure that the established goals provide students with a challenge. } \\
\text { - Use goals as a motivational factor for engagement; for example, if all students achieve a goal, } \\
\text { then they receive a reward. (Note: Use sparingly, as students will always expect a reward if used too } \\
\text { frequently) }\end{array}$ \\
\hline Self-System of Learning & $\begin{array}{l}\text { - Have students identify their perceived ability to complete a given task. } \\
\text { - Utilize questionnaires that identify a student's strengths and weaknesses. } \\
\text { - Provide students with assignments or tasks that play on their strengths. } \\
\text { - Engage in conversation with students regarding their interests, allowing you to learn from their } \\
\text { stories and experiences. }\end{array}$ \\
\hline Importance of the Lesson & $\begin{array}{l}\text { - Explicitly state why the lesson is important for students. } \\
\text { - Utilize students' interests to convey the importance of a lesson. } \\
\text { - Tie the importance of the lesson into the anticipatory set or preflection. } \\
\text { - The use of an interactive activity to convey the importance of a lesson can increase student } \\
\text { motivation. }\end{array}$ \\
\hline Self-Efficacy & $\begin{array}{l}\text { - Utilize questionnaires to determine students' self-efficacy towards the course material. } \\
\text { - Utilize goals that are achievable by the students to increase their self-efficacy. } \\
\text { - Engage in conversation with your students about their academic careers to determine if the } \\
\text { students have developed learned helplessness. } \\
\text { - Engage in positive interactions with the student by attending sporting events, discussing their } \\
\text { personal interests, or integrating their interests into a lesson. }\end{array}$ \\
\hline Student Emotions & $\begin{array}{l}\text { Determine the typical behavior of your students } \\
\text { - If a student seems distressed, have a private conversation with the student and determine if further } \\
\text { assistance is needed } \\
\text { - If possible, help students (typically by soliciting the help of a guidance counselor) through an } \\
\text { emotional dilemma by ensuring that they are fed, sheltered, and feel safe. } \\
\text { - Ensure that all students are treated equally and feel safe within your classroom by utilizing positive } \\
\text { feedback and interaction with peers. }\end{array}$ \\
\hline
\end{tabular}

